\title{
Etiese perspektiewe op haatspraak in die lig van die derde gebod
}

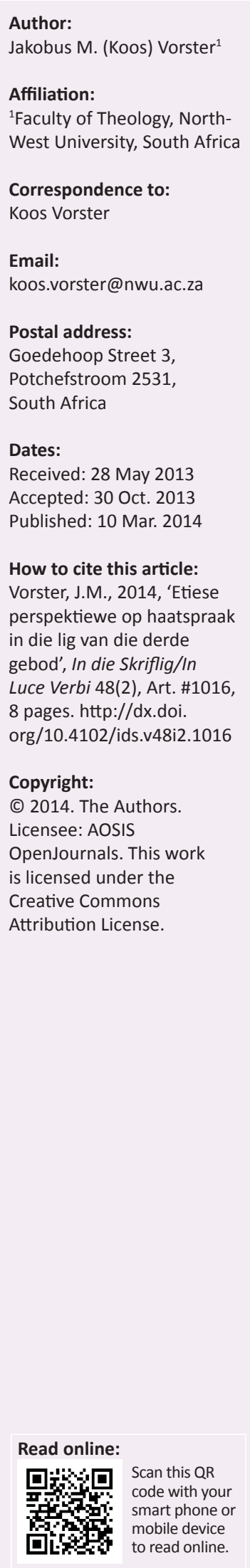

Hierdie artikel fokus op die implikasies van die derde gebod met betrekking tot haatspraak in Suid-Afrika (SA) vandag. Die artikel gaan uit van die standpunt dat die name van God op sy wese dui. Die name van God soos dit in die bybelse openbaringsgeskiedenis ontwikkel word, druk die gemeenskapskarakter van God se verhouding met mense en die skepping uit. Die betekenis van die name kulmineer in die Nuwe-Testamentiese uitdrukkings Vader en God is liefde. Alle verbale gedrag wat hierdie gemeenskaps- en liefdesverhouding inhibeer, oortree die derde gebod. Die misbruik van die Naam van God vind onder andere plaas wanneer mense, wat na die beeld van God geskep is, gedegradeer word deur haatspraak, omdat sodanige degradering die gemeenskap en liefde tussen God en die mens skend. Ten slotte word sekere gevalle van haatspraak soos dit vandag in Suid-Afrika voorkom, teologies-eties belig teen die agtergrond van die betekenis van die derde gebod. Hierdie vorms sluit religieuse, rassistiese, xenofobiese, seksistiese en homofobiese haatspraak in.

Ethical perspectives on hate speech in view of the third commandment. This article focuses on the implications of the third commandment for hate speech in modern-day South Africa. The article contends that the names of God are expressions of his Being. The names of God as they are developed in the biblical history of revelation express his creation of covenantal community and restored relations with humankind and creation. The meaning of the names of God culminates in the New Testament expressions Father and God is love. Verbal actions that inhibit the new community created by God or violate love transgress the third commandment. Misuse of the name of God occurs among others when people, created in the image of God, are verbally degraded by hate speech because such degradation violates the community of love between God and humankind. In conclusion, the article indicates forms of hate speech in South Africa that should be dealt with in the light of the third commandment. These are acts of racist, xenophobic, sexist, religious and homophobic hate speech.

\section{Inleiding}

In navolging van die Universele Deklarasie van Menseregte (United Nations [UN] 1948) soos die dokument in verskeie grondwetlike demokrasieë gerealiseer het, beskou die 1996-Grondwet van die Republiek van Suid-Afrika (SA 1996) vryheid van uitdrukking as 'n fundamentele reg. Die eerste deel van artikel 16 van die hoofstuk oor die Handves van Regte lui soos volg:

1. Elkeen het die reg op vryheid van uitdrukking, waarby inbegrepe is -
a. die vryheid van die pers en ander media,
b. die vryheid om inligting en idees te ontvang of oor te dra,
c. die vryheid van artistieke kreatiwiteit, en
d. akademiese vryheid en vryheid van wetenskaplike navorsing. (bl. 9)

Hoewel vryheid van uitdrukking sedert die begin van die moderne diskoers oor menseregte as ' $n$ fundamentele reg erken word, het daar toenemend die standpunt posgevat dat sommige uitdrukkings wat as haatspraak getipeer kan word, nie beskerm behoort te word nie (Kiska \& Coleman 2012:129). In die lig van hierdie wêreldwye ontwikkeling het die Grondwet van SuidAfrika ook 'n beperking op die vryheid van uitdrukking geplaas. Hierdie beperking lui soos volg (SA 1996):

1. die reg in subartikel (1) omvat nie -

a. propaganda vir oorlog nie,

b. die aanstigting van dreigende geweld nie; of

c. die verkondiging van haat wat op ras, etnisiteit, geslagtelikheid of godsdiens gebaseer is en wat aanhitsing om leed te veroorsaak, uitmaak nie. (bl. 9)

In die lig van hierdie beperking word haatspraak afgewys. Die vraag is egter wat presies as haatspraak beskou word. Volgens Devenish (1999:211) is haatspraak 'expressive conduct which 
insults a racial or ethnic group, whether by suggesting inferiority or by effecting exclusion'. Haatspraak in hierdie konteks is 'n misdaad en dit word as sodanig wyd erken en deur die Verenigde Nasies (UN 1995:221) as sodanig gepropageer. ${ }^{1}$

In hierdie artikel word haatspraak vanuit 'n teologiesetiese perspektief teen die agtergrond van die derde gebod ondersoek. Hierdie gebod lui: 'Jy mag die Naam van die Here jou God nie misbruik nie, want die Here sal die een wat sy Naam misbruik nie ongestraf laat bly nie' (Eks 20:7, Nuwe Afrikaanse Vertaling). Die sentraal teoretiese argument van hierdie artikel is dat 'n teologies-etiese perspektief, met die verbod van die derde gebod as uitgangspunt, 'n besondere bydrae tot die definiëring van haatspraak lewer. Vanuit hierdie definisie behoort die Christelike etiek ondersteuning te bied aan die verbod op haatspraak soos dit byvoorbeeld na vore kom in seksistiese, rassistiese, religieuse, homofobiese en ander interpersoonlik-degraderende gedrag. Voorts behoort godsdiensvryheid ook nie aangewend te word as 'n vrypas om onder die dekmantel van die bevordering van godsdiens degraderende spraak ten opsigte van mense van ander oortuigings goed te keur nie. ${ }^{2}$

Die argumentasielyn van hierdie artikel begin met 'n teologiese ontleding van die derde gebod, waarna die kontemporêre etiese norme wat daaruit voortvloei, blootgelê word. Hierdie norme word dan vervolgens op bepaalde vorms van haatspraak toegepas in 'n poging om vanuit 'n gereformeerde teologies-etiese perspektief koers aan te dui in die etiese hantering van hierdie vraagstuk binne die raamwerk van vryheid van spraak en godsdiensvryheid.

\section{Die derde gebod}

Die vertaling van die derde gebod lewer enkele probleme op. Harman (1988:10) wys daarop dat die gebod soos dit in Eksodus 20:7 en Deuteronomium 5:1 gestel is, identies is sowel in die Masoretiese teks as in die Septuagint. Hoe moet dit egter vertaal word? 'n Ou vertaling lui volgens Harman (1988:1) soos volg: 'You shall not swear falsely by the name of the Lord your God'. Hierdie vertaling word op ou Joodse kommentare en die Peshitta gegrond. Indien hierdie vertaling korrek is, lei dit tot ' $n$ baie eng interpretasie van die derde gebod. Harman (1988:1) is van mening dat 'n eng interpretasie soos uit hierdie ou vertaling van die teks afgelei word, nie reg aan die derde gebod laat geskied nie. Hy grond dit op die inbedding van die gebod in die verbondsverhouding

\footnotetext{
1.Die konvensie roep die state op om alle propaganda wat die idee van rassemeerderwaardigheid bevorder en organisasies wat daarby betrokke is, te veroordeel en verder dat hulle: (a) Shall declare an offence punishable by law all dissemination of ideas based on racial superiority or hatred, incitement or racial discrimination, as well as all acts of violence or incitement to such acts against any race or group of persons of another colour or ethnic origin, and also the provision of any assistance to racist activities, including the financing thereof; (b) Shall declare illegal and prohibit organisations, and also organised and all other propaganda activities which promote and incite racial discrimination, and shall recognise participation in such organisation or activities as an offence punishable by law; (c) Shall not permit public authorities or public institutions, national or local, to promote or incite racial discrimination.

2.Die botsing tussen vryheid van godsdiens en die verbod op haatspraak word ' $n$ groeiende probleem. Godsdienste is per definisie teen immorele gedrag wat as immoreel gedefinieer word in gevolge die morele norme wat ' $n$ betrokke godsdiens belangrik ag. Uitsprake teen homoseksuele gedrag op grond van godsdienstige norme het al gelei tot klagtes voor howe van haatspraak (vgl. Kiska \& Coleman 2012:130). Grim (2012:31) toon aan dat daar 'n toenemende beperking op godsdienste geplaas Grim (2012:31) toon aan dat daar ' $n$ toenemende beperking op godsdie
word, onder andere omdat haatspraak godsdienstig geregverdig word.
}

tussen God en sy volk soos uitgedruk in die inleiding van die wet in Eksodus 20:2. Die konteks waarin die derde gebod aangekondig word, is volgens hom dus belangrik. Die Tien Gebooie handel oor die eksklusiewe eise wat God aan sy verbondsvolk stel. Die oordeel wat in hierdie gebod uitgepreek word, bewys dit, want in die Nabye Ooste het verbonde met seëninge en oordele gepaard gegaan. Met verwysing na verskeie Ou-Testamentiese navorsers oor hierdie saak kom Harman (ibid:4) tot die gevolgtrekking dat dit in die derde gebod oor die gedrag van die gelowige handel en nie net oor sy spraak nie. Die volk moes in al hulle handelings toon dat hulle trou is aan God en hulle identiteit as uitverkore verbondsvolk handhaaf.

In sy teologies-etiese beoordeling van die Tien Gebooie gee Douma (1996:73) breedvoerig aandag aan die wye betekenis van die derde gebod. Vir hom lê die kern van die verbod in die derde gebod daarin dat die Naam van die Here nie gelaster of misbruik moet word deur dit vir valse doeleindes te gebruik nie. Hieronder noem hy towery, valse profesie en onnodige en valse eedswering. Die verbod gaan egter ook wyer. Om die wye betekenis aan te dui, heg hy besondere waarde aan die feit dat God hier in die derde persoon spreek - anders as in die eerste twee gebooie. Die naam van God dui sy wese aan en hy grond die stelling op verskeie Skrifgedeeltes in die Ou Testament. Hy wys in die besonder op die koppeling van naam en wese in Psalm 8. God se naam is diep met sy wese verweef as Skepper en Onderhouer van alle dinge en sy verbondsverhouding met mense. God gebruik daarom die verbondsnaam JHWH. Douma (1996) kom tot die gevolgtrekking:

... that attacking one of God's creatures can be an attack upon
the name of the Lord. Anyone who mocks the poor insults their
Maker [Spreuke 17:5]. You may not curse a deaf person or put a
stumbling block in front of a blind person [Levitikus 19:14]. These
actions also violate the third commandment. (p. 76)

Hoewel Douma (1996:80) verder gaan en die derde gebod toepas op vloekery, misbruik van die naam van God en Christus in die algemene taalgebruik, die gebruik van die eed, swye wanneer die naam van God misbruik word en loting, is sy koppeling van die naam van JHWH en sy wese 'n belangrike uitgangspunt wat verder beredeneer moet word. Hierop word vervolgens ingegaan.

\section{Naam en wese in die Ou Testament}

As uitgangspunt in hierdie bespreking van die naam en wese van God word 'n openbaringshistoriese benadering gekies soos dit in die Protestantse tradisie ontwikkel is, veral deur Cullmann (1948:157) en Barth (1961:136) en soos dit in die gereformeerde Ou-Testamentiese besinning beslag gekry het. Hierdie benadering word soms as heilsgeskiedenis, verbondsgeskiedenis of Salvation history getipeer. Hiervolgens word die hele Skrif as die openbaring van God se voortgaande handelings in die geskiedenis van die verbondsvolk gesien (Reuman 2005:833). Die uitgangspunt is dus die eenheid van die Ou Testament binne die verskeidenheid en diversiteit van geskiedenisse en verhale soos dit ook deur Goldingay (2006:170) 
uitgewys word. Deur die voortgaande handelings van God word Hy en sy verlossingswerk algaande meer duidelik geopenbaar en uiteindelik mond dit uit in die soenverdienste van Christus as die sentrum van die verlossingsgeskiedenis. Vir 'n bespreking van die verhouding tussen die naam en die wese van God is die keuse van 'n openbaringshistoriese benadering belangrik, omdat sodanige benadering ' $n$ ander lig sal laat val op die verklaring van die derde gebod as byvoorbeeld die benadering van die bronnehipotese.

In die Oud-Oosterse kultuur het die naam van 'n persoon dikwels die persoon se karakter en identiteit uitgedruk (Routledge 2008:81). In daardie tyd se godsdienste is soms geglo dat kennis van die naam van 'n spesifieke god aan 'n persoon toegang tot die krag van daardie god verleen en hierdie krag kan aangewend word om op 'n magiese manier die betrokke god te manipuleer. Routledge (ibid:82) aanvaar dat dit om hierdie rede is dat God die misbruik van sy naam deur die volk in die derde gebod verbied het. God se name openbaar iets van sy wese. Hoewel die Godsopenbaring, veral die Godsname, 'n diep misterie is, sê die name iets van die wese en eienskappe van God. God kan geken word alleen daar waar Hy Homself deur sy Naam bekend maak. Buite hierdie openbaring om is Hy onkenbaar. Brunner (1949) stel dit so:

The 'Name' is that which is peculiar to Himself, it is that which distinguishes Him from all else, that which cannot be expressed by any general conception; which is not an object of human knowledge of any kind; we cannot discover it. (p. 120)

Name wat in die derde gebod gebruik word, is JHWH (Here) en Elohim (God) (MT). Hoewel Elohim 'n soortnaam is, is die kenmerk van hierdie benamings dat dit op God as 'n persoon dui. Elkeen van hierdie name druk ook iets besonders van God uit. God is 'n persoon wat in 'n persoonlike verhouding met sy volk en met elkeen individueel leef (Brunner 1949:122). Teen hierdie agtergrond wys elke benaming ook nog op ander spesifieke eienskappe van God.

Die naam Elohim verwys volgens Routledge (2008:82) na God (bv. in Gen 1:1; Eks 3:6; Deut 4:35; Jes 40:28). Soms dui die naam ook op die gode van ander nasies (bv. Eks 12:12; 20:3; Jos 24:15; Ps 96:5; Jer 2:28; 11:13). Die gebruik van die meervoudsvorm dui volgens hom op die majesteit van God. As sodanig kan God gesien word as die sentrum van die Ou Testament (Hasel 1991:168). Hy openbaar Homself nie as iets abstraks nie, maar is volgens Hasel (ibid:169) lewend teenwoordig in die doen en late van mense en die voortgang van die wêreldgebeure. Hierdie selfopenbaring van God is volgens Vriezen (1966:374) deel van God se 'revelatio generalis omdat die naam ten nouste betrek word op die skepping en die natuur'. Elohim dui dus op die heerskappy van God oor die hele aarde en op sy magtige dade in die skepping, onderhouding en regering van alle dinge. Hy is almagtig maar aktief teenwoordig in die lewe van sy kinders. Juis vanweë die almag en die majesteit van God moet sy naam met eerbied en respek gebruik word en mag Hy nie gelaster word nie.
Nóú verwant aan Elohim is die benaming El, hoewel hierdie benaming nie in die derde gebod gebruik word nie. Volgens Routledge (2008:83) is hierdie benaming ' $n$ generiese naam vir god. Dit word in die Ou Testament 199 keer vir die God van Israel gebruik (teenoor die meer as 2000 keer van Elohim). In die patriargale verhale word hierdie benaming aan ander benamings gekoppel soos El Shaddai (God die Almagtige Gen 17:1; Eks 6:2) en El Elyon (God die Allerhoogste - Gen 14:18-20). Hierdie benaming soos deur die verbondsvolk van die Ou Testament vir God gebruik, dui net soos Elohim op die alles-oorkoepelende en alles-oorheersende majesteit en regering van God. Daarom moet sy naam met die hoogste eerbied en respek gebruik word.

Die naam JHWH kom in die Ou Testament voor as 'n beskrywing van die gemeenskapskarakter van die Israelitiese godsdiens. Die godsdiens van die Ou Testament is gegrond in die verbond wat ten diepste om die gemeenskap van God met die mens gaan. Vriezen (1966) het van hierdie gemeenskap tussen God en die mens as 'n deurlopende lyn in die $\mathrm{Ou}$ Testament ' $\mathrm{n}$ besondere studie gemaak. Onder die opskrif 'Het verkeer van God en mens', behandel hy die openbaring van God, die kultus van die volk en die vroomheid wat opgeëis word. Hy beskryf JHWH as die God van die gemeenskap, van die gemeenskapsvorms, die gemeenskapsnorms en die mens binne hierdie gemeenskap wat tussen God en die mens bestaan. Onder die titel 'JHWH, de God der gemeenschap', behandel hy die name van God (Vriezen ibid:370). Die name dui dus op die wese van God as die allesomvattende heerser wat tog ook as Verbondsgod in 'n persoonlike verhouding met sy volk leef.

Oor die oorsprong van die naam is daar nie duidelikheid nie, maar die God van Israel is JHWH genoem om Hom van die Oud-Oosterse gode te onderskei. Eerstens wys hierdie naam op die teenwoordigheid van God. Anders as die gode van die ou Oosterse godsdienste was JHWH die God wat op 'n besondere wyse by sy volk teenwoordig was. De Vaux (1988:327) dui aan dat JHWH orals was waar sy naam teenwoordig was. Hierdie teenwoordigheid is 'n uitdrukking van sy genade. Hy het verkies om onder sy volk te woon en hierdie teenwoordigheid is deur die verbondsark en later deur die tempel gesimboliseer. God het Sion gekies 'en dit vir Hom as woning begeer'; (Ps 132:13). Hy het ook die berg van Sion 'as 'n woning verkies' (Ps 68:17). De Vaux (1988:327) wys in hierdie verband ook op Deuteronomium 12:5 wat lui:

Julle moet na die wil van God gaan vra op die plek wat die Here julle God sal kies uit al die stamgebiede om sy Naam daar te vestig en daar te woon.

As sodanig kom die konsep 20 keer in Deuteronomium voor en vir die gelowiges van die $\mathrm{Ou}$ Testament is die teenwoordigheid van God, gesimboliseer deur die tempel, ' $\mathrm{n}$ bron van troos en inspirasie.

Brueggemann (2009:19) beklemtoon die gemeenskapskarakter van JHWH van 'n enger tot wyer horisonne. God het vennote en volgens die Ou-Testamentiese openbaring is daardie 
vennote die verbondsvolk Israel, die mens as beeld van God, die nasies en die hele skepping. Brueggeman brei op elkeen van hierdie uitkringende vennootskappe uit. Die verbondsvolk is deur JHWH gekies en as vennoot geroep en hierdie vennootskap gaan oor op die Nuwe-Testamentiese kerk as die 'Israel van God' (Gal 6:15-16; Brueggemann ibid:54). Die verbondsvolk is die enger horison. Die mens is vennoot van JHWH omdat hy na God se beeld geskape is en omdat die sorg van die skepping aan hom toevertrou is. Hierdie beeldskap word nie met die sondeval opgehef nie en dit roep die mens tot menslikheid (Brueggemann ibid:59). Israel is egter die mikrokosmos van die 'mensheid' (Goldingay 2006:517). Deur Israel word die nasies ook vennote van God. Israel moet die majesteit van God aan die nasies bekendmaak (Ps 96:10) en so die middelaar wees van God se band met die nasies. Die nasies word die wyer horison van God se heerskappy (Brueggemann ibid:100). Die ganse skepping is in 'n verbondsverhouding met JHWH soos blyk uit die skepping en die Noagitiese verbond (Brueggemann ibid:101). Die skepping is die wydste horison van JHWH se heerskappy. Ook hierdie verhouding moet deur Israel, die verbondsvolk, bemiddel word. Brueggemann (ibid) sê:

As we have seen with Israel's testimony about the human person as JHWH's partner, in this case as well it seems clear that Israel's own lived experience and sense of itself vis-à-vis JHWH matter greatly in determining how Israel bears witness to creation as JHWH's partner. As with other partners, creation as JHWH's partner is read through Israel's sense of itself. (p. 137)

\section{Naam en wese in die Nuwe Testament}

$J H W H$ is die Verbondsgod wat in 'n verhouding tree met sy volk, met persone, met die nasies en met sy skepping. Ingebou in hierdie verhoudings lê die hele teologie van genade en versoening. Daar kan geargumenteer word dat hierdie versoening soos in die gemeenskapskarakter van die Ou Testament vergestalt, openbaringshistories op die Christologie van die Nuwe Testament uitloop. Christus kom om gebroke verhoudings te herstel en dus die verhoudings tot in die wydste horison nuut te maak. Die versoening in Christus (deur die bloed en offer van Christus) herstel die skeppingsverhoudings soos in die $\mathrm{Ou}$ Testament in die naam JHWH uitgedruk is. Daarmee gaan die beloftes van die Ou-Testamentiese heilige handelings, feeste en simbole in vervulling. Volgens Gloer (2007:597) is versoening in Christus op die eskatologiese restourasie van alle dinge gerig. Die uitdrukking in Christus omskryf die nuwe bestaanswyse van die mens wat in Adam 'n gebroke bestaanswyse gevoer het. Mense ontvang 'n nuwe bestaanswyse wat afgelei word van hulle betrokkenheid by die kruisgebeure (Campbell 2003:45). Die kerk as vergadering van versoende kinders van God, word die sigbare teken van hierdie nuwe bestaanswyse (Farrow 2003:67; Turner 2007:44). Deur die inlywing in Christus verander die mens weer van god teenoor God na kind en erfgenaam van God. Die mens kan weer vrede hê met God deur Jesus Christus, die Here (Rom 5:1). Mense se interpersoonlike vyandskap word opgehef omdat almal deur die geloof aan Christus se liggaam deel het (Gal 3:28). Daar moet ook met die vyand in liefde saamgeleef word, want alle skeppingsverhoudings verander. Die sondaarmens se heerssugtige dominansie van die natuur verander in 'n gesindheid van rentmeesterskap en verantwoordelike versorging. Samevattend kan dus in hierdie verband gesê word dat die versoening in Christus 'n soteriologiese, Christologiese, ekklesiologiese en kosmologiese dimensie het (Patterson 2003:139; Johnson 2005:23; Willmer 2007:152).

Die gemeenskapskarakter soos dit in die Ou Testament in die naam JHWH uitgedruk word en in die Nuwe Testament in die Christologie vergestalt word, word verder belig in die gebruik van die metafoor volk van God, die Vadermetafoor en die uitdrukking God is liefde. Al hierdie dien as beskrywing van die gemeenskapskarakter van God in die Nuwe Testament.

Küng (1992:107) is van mening dat die Ou-Testamentiese begrip volk van God die denke oor die kerk in die Nuwe Testament wesenlik beïnvloed het. Die dissipels het die metafoor op hulleself van toepassing gemaak. Teenoor die ander godsdienstige groepe soos die Esseners en die Fariseërs het hulle hulleself as die ware en nuwe Israel beskou. Küng sien dus ' $n$ historiese simboliese band tussen die uitdrukking in die Ou Testament en dié in die Nuwe Testament. Ridderbos (1971:364) het vroeër tot dieselfde gevolgtrekking gekom in sy navorsing oor die teologie van Paulus.

In sy behandeling van die begrip koninkryk van God in die Nuwe Testament het Bright (1963:71) aangetoon dat dit in die uitdrukking om veel meer gaan as slegs ' $n$ historiese verband. Die kerk as volk van God is vir hom 'n vervulling van wat die begrip in die Ou Testament uitgedruk en beloof het. Die geskiedenis van Israel was benewens hulle gehoorsaamheid, ook dikwels 'n geskiedenis van ontrou en goddeloosheid. Tog het God telkens sy verbond met hulle weer bevestig. Hoewel hulle geoordeel word en uiteindelik in ballingskap weggevoer word, is daar 'n klein oorblyfsel wat hulle tot God bekeer. Hierdie oorblyfsel is in heilshistoriese en nie net historiese sin nie, die volk van God. Ridderbos (1969:4) beskryf om dieselfde rede die volk van God in die Ou Testament as die volk wat hulle unieke bestaan en verwagting gevind het in die teokratiese regering van God. Hulle was dus die volk van God se koninkryk wat met messiaanse heilsverwagting geleef het (Vriezen 1966:476).

Met die koms van Christus breek die koninkryk van God deur in die harte van mense uit alle volke, tale en nasies. Hulle wat gelowig op die groot genadige herskeppingsdaad van God reageer, wat buig voor die nuwe Koning, wat die kruis begryp en omhels, hulle word deur die koninkryk in besit geneem. In moderne taal kan gesê word dat hulle burgers word van die koninkryk, of die volk van die koninkryk. Die volk van God in die Nuwe Testament is die openbaringshistoriese voortsetting van die volk van God, Israel, in die Ou Testament (Ridderbos 1971:364). Die eenheid lê in Christus en daarom word verskeie Ou-Testamentiese benamings vir die Nuwe-Testamentiese kerk gebruik soos Israel (Rom 9:6), priesterdom (1 Pet 2:5, 9), tempel (1 Kor 3:16) en liggaam (Kol 1:18). 
Volgens Gassmann (1968:290) wil die metafoor volk van God juis die eenheid van die ou en die nuwe verbond beklemtoon. Dit beteken dat die Here sy volk in aansyn roep, lei, regeer en bewaar dwarsdeur die wêreldgeskiedenis. Hierdie versekering lê in die metafoor volk van God opgesluit. Hierdie uitdrukking karakteriseer die kerk as ewig, uniek, onvernietigbaar en bo die magte van die geskiedenis verhewe. Die openbaring aangaande die kerk wat deur die metafoor volk van God belig word, word verder met ander benamings aangevul, naamlik uitverkorenes, uitgeroepenes, gelowiges en geliefdes (Ridderbos 1971:368). Al hierdie beskrywende begrippe dui aan dat daar tussen God en die gelowiges en tussen die gelowiges onderling 'n besondere verhouding bestaan. Soos 'n volk 'n eie etos het, het die kerk as volk van God 'n eie etos wat in die gemeenskapskarakter geleë is. Hierdie gemeenskapskarakter is die vrug van Christus se versoeningswerk. Dit gaan dus in die kerk van die Nuwe Testament oor die gemeenskap van gelowiges wat deur die versoening van Christus tot stand gebring word. Dit gaan egter ook om meer. Dit gaan oor nuwe verhoudings met alle mense en ook met die skepping. Die uitkringende gemeenskap sluit aan by die wyerwordende horisonne wat die Godsnaam JHWH uitdruk.

Hierdie gemeenskapskarakter word treffend in die Vadermetafoor uitgedruk wat veral sentraal staan in die gebed wat Jesus leer (Matt 6:9-13), asook in sy hoëpriesterlike gebed (Joh 17:1-26). In Christus word God die Vader van sy kinders en dit dui op die besondere gemeenskapskarakter van die huisgesin van God. In sy studie oor hierdie benaming van God dui Finlayson (1970:466) aan dat hierdie begrip reeds in die Ou Testament teenwoordig was waar dit 'n teokratiese en skeppingsverhouding uitgedruk het. Hy verwys na Maleagi 2:10 en Jesaja 64:8. Daar moet bygesê word dat die $\mathrm{Ou}$ Testament ook die moedermetafoor gebruik. Soos die vadermetafoor, dui die moedermetafoor op die gemeenskapskarakter van die verhouding van God en die godsvolk (Deut 32:11, 12; Jes 42:14; 49:15; vgl. ook Dille 2004:72, 150). Vroulike beskrywings van God wat op dieselfde idee dui, kom ook in die Nuwe Testament voor (Matt 23:37). Jesus het egter aan die vadermetafoor ' $n$ meer spesifieke betekenis gegee. Hy is die Seun van sy Vader, maar deur Hom word mense ook kinders van die Vader. As kinders word hulle ook erfgename van God, saam met Christus (Rom 8:17). Finlayson (1970) sê verder:

It is under this relationship of Father that the New Testament brings out the tenderer aspects of God's character, His love, His watchful care, His bounty, and His faithfulness. (p. 466)

Die tipering van die wese van God word verder ingeklee deur die uitdrukking in 1 Johannes 4:8: 'God is liefde; wie in die liefde bly, bly in God en God in hom (haar).' Hierdie liefde is die kenmerk van die intertrinitêre verhouding soos uitgedruk in Johannes 5:20 en 14:31 (Packer 1988:277). Dit is opmerklik dat die Griekse woord agape hier gebruik word. In sy teologiese beredenering van hierdie begrip dui Barth (1961:68) aan dat dit hier om die ware natuur van die mens gaan, naamlik as geskape in 'n verhouding met God. Hierdie liefde is dus ' $n$ verhoudingsbegrip en dui in die besonder op God wat in verhouding staan met mense (vgl. ook Moltmann 1993:216). Hierdie liefde word ook van die kinders van God geëis. Gelowiges moet, as vervulling van hulle dankbaarheidslewe, liefde aan God en aan hulle naaste bewys. Liefdeloosheid druis in teen hierdie wesenskenmerk van God.

Samevattend kan dus gesê word dat die name van God soos dit in die derde gebod gebruik word en openbaringshistories in die Nuwe Testament belig word, besondere elemente van die wese van God belig. Wie die naam van God aantas, tas sy Wese aan. Wie die naam van God aantas, tas sy verbondsgemeenskap met die mens en sy verbondsliefde aan. Die omgekeerde is ook waar: wie die verbondsgemeenskap met God in al sy wyer horisonne aantas, tas God self aan. Wie liefdeloos optree, ondermyn die liefde van God.

\section{Die derde gebod toegepas op enkele moderne vorms van haatspraak}

In die lig van die derde gebod soos die betekenis daarvan openbaringshistories ontwikkel word, kan die volgende teologies-etiese definisie van haatspraak aan die hand gedoen word: Haatspraak dui op alle gedrag van mense wat die liefdesgemeenskap wat God tot stand bring, ondermyn en selfs vernietig. Hierdie gedrag kan uit afbrekende taal, lyftaal, humor, komiese voorstellings, vloekery en degraderende beskrywings van mense bestaan.

Hoewel dit verstaanbaar is dat nie alle vorms van haatspraak juridies strafbaar gemaak kan word nie moet die fenomeen uit ' $n$ teologies-etiese hoek ook belig word en moet daar norme neergelê word om dit in intermenslike verkeer in die proses van nasiebou te bestry. Juridies moet gekyk word na haatspraak wat 'n bepaalde skadelike verlede heropen en 'n sekere deel van die gemeenskap degradeer. In hierdie opsig is anti-Semitisme in Duitsland en rassisme in SuidAfrika sprekende voorbeelde. Tog is dit nie net hierdie soort haatspraak wat skade doen en goeie verhoudings inhibeer nie. Haatspraak wat nie noodwendig strafbaar is nie, moet ook gedefinieer en aktief deur morele agente bestry word. In hierdie opsig is 'n teologies-etiese benadering tot die vraagstuk waardevol en kan dit 'n groot bydrae lewer tot die morele ontwikkeling van mense - tot so 'n mate dat hulle 'n sensitiwiteit vir die afbrekende gevolge van alle vorms van haatspraak ontwikkel.

Om die waarde van so 'n etiese benadering te illustreer, word enkele praktiese voorbeelde soos dit in die Suid-Afrikaanse samelewing voorkom, aan die orde gestel:

- Haatspraak op godsdienstige gronde: Binne godsdienstige kringe word haatspraak dikwels geregverdig met die skyn van reg en die beroep op die waarheid. Vanuit 'n invalshoek dat die spreker die waarheid aan sy of haar kant het, word mense met sienings wat daarteenoor staan as afwykend beskou en met allerlei afbrekende terme getipeer. Hieronder kan terme genoem word soos sektes en sektaries, fundamentaliste, liberaliste, heidene, 
ketters, dwaalleraars, humaniste en fanatici. Godsdienstige mense word as dwepers getipeer. Mense van bepaalde godsdienstige oortuigings gebruik dikwels degraderende taal om na ander godsdienste te verwys soos infidel, die term wat Moslems gebruik om mense van ander oortuigings te tipeer. Wetgewing om godsdienstige simbole te verbied, word soms met vorms van haatspraak geregverdig. Die betoog van die voormalige president van Frankryk, Sarkozy, ten einde die dra van die burq'a deur vroue van Islamitiese oortuiging met wetgewing te verbied, is ' $n$ sprekende voorbeeld hiervan (Bremner 2010:1; vgl. ook Vorster 2011:63). Spotprente van die profeet Mohammed en ligsinnige uitbeeldings van Christus word met die fundamentele reg van vryheid van spraak geregverdig. Godsdiens en geloof lê diep in mense se emosies ingebed en godsdienstige haatspraak kan maklik in dade van aggressie ontlaai en selfs tot openlike geweld oorgaan soos die toename in godsdienstig-gemotiveerde geweld in die jongste verlede getuig. Godsdienstige instellings en godsdiensleiers het die taak om hierdie vorm van haatspraak aan bande te lê. Hierdie opdrag geld soveel te meer vir Christene, omdat godsdienstig-gemotiveerde haatspraak die derde gebod oortree.

- Rassistiese en xenofobiese haatspraak: Schutte (1995) sê dat 'n ras 'n groep mense omskryf:

(that) construct themselves on the basis of language, religion, culture, descent, or a combination of these and other features. An ethnic group may even shift the basis on which it constructs its identity from one feature to another. Historical ethnic groups may merge and found their solidarity on a new basis. (p. 18)

Rassisme kan in die lig hiervan beskryf word as die gesindhede en dade van haat, vooroordeel en diskriminasie van een groep mense teenoor 'n ander of teenoor groepe. Xenofobie dui op dieselfde gesindheid teenoor vreemdelinge. Haatspraak in hierdie verband is verbale gedrag waardeur hierdie haat, vooroordeel en vyandskap uitgedruk word. Rassistiese haatspraak word deur die Verenigde Nasies (UN 1995:221) as 'n misdaad beskou en lidstate is versoek om dit met wetgewing te bestry. Dit is ook die geval in Suid-Afrika. Uit'n teologiesetiese hoek moet geoordeel word dat haat en vooroordeel van een groep teenoor ' $\mathrm{n}$ ander immoreel is. Dit word veral gesien in die lig van die feit dat die versoening in Christus, uitgedruk in die Naam van God, alle grense oorbrug. Rassistiese en xenofobiese haatspraak moet dus op etiese en juridiese gronde afgewys word. Die sterk verbod op hierdie soort haatspraak in Suid-Afrika is te verstane, gesien in die lig van die lang Suid-Afrikaanse geskiedenis van rassediskriminasie en vooroordeel teenoor vreemdelinge. Die groot hoeveelheid sake van rassistiese haatspraak wat by die Suid-Afrikaanse menseregtekommissie aangemeld word, toon dat daar ' $n$ betekenisvolle neiging is om hierdie soort haatspraak in Suid-Afrika te bestry. Tog is rassistiese en xenofobiese haatspraak 'n vorm van haatspraak wat wêreldwyd toenemend voorkom soos wat emigrasie toeneem en gemeenskappe hulle homogeniteit verloor. Hiervan gee Bestler (2013:10) goeie voorbeelde. Benewens die regsoptredes wat die Verenigde Nasies in hierdie verband bepleit, moet alle morele agente en veral die kerke erns maak om ook hierdie vorms van haatspraak te bestry, juis omdat dit die idee van gemeenskap en die herstel van verhoudings ondermyn soos dit in die derde gebod uitgedruk word.

- Seksistiese haatspraak: Die feministiese teoloog Schüssler-Fiorenza (1998:230) en Camp (1990:506) het in die negentigerjare van die vorige eeu aangetoon dat godsdiens 'n groot rol in die seksisme speel wat nog prominent in sekere samelewings voorkom. Seksisme beskryf die siening dat vroue inherent minderwaardig is en dat hierdie mindere posisie in die samelewingstrukture gerealiseer mag word. Hierdie beskouing het sterk religieuse wortels en kan teruggevoer word na die antropologie van feitlik al die hoofstroomgodsdienste en tradisionele Afrika-godsdienste (Vorster 2007:185). Hoewel die bevryding van die vrou in die moderne westerse samelewings toegeneem het, kom daar steeds baie diskriminasie teen vroue in ontwikkelende en godsdiensoorheersde samelewings voor. Daarom is hierdie verskynsel al lank reeds op die agenda van die Menseregteraad van die Verenigde Nasies (UN 1996). Seksistiese haatspraak teer op hierdie skynbaar vroom godsdienstige bodem. Dit wissel van openlike vernedering van vroue in degraderende dade tot die dehumaniserende uitbeeldings van die vroulike liggaam. In Suid-Afrika is geweld teen vroue endemies en haatspraak in die vorm van onvleiende humor kom wyd voor. Verskeie Christelike teoloë het reeds aangetoon dat die Bybel inderdaad die ongelyke posisie van die vrou in die antieke kulture deurbreek het en die volledige bevryding van die vrou in die samelewingstrukture propageer. Hierdie ontwikkeling is elders breedvoerig bespreek (Vorster 2007:190). Seksisme ondermyn die nuwe gemeenskap wat Christus met sy versoeningsoffer daargestel het, asook die gemeenskapskarakter wat deur die name van God uitgedruk word. Seksistiese haatspraak ondermyn ook die strewe na die erkenning van die gelykwaardigheid van die vrou en die manifestering om aan die gelykwaardigheid van die vrou beslag te gee. Om hierdie rede is seksistiese haatspraak in stryd met die derde gebod, al geskied dit ook by wyse van humor en satire. As deel van hulle onderhouding van die derde gebod het veral kerke en Christene die taak om seksistiese haatspraak te vermy en daadwerklik teen te gaan. As morele agente is dit ook die taak van die owerhede om deur middel van opvoeding en onderwys die minderwaardige posisie van vroue in die SuidAfrikaanse kultuur te deurbreek en die gelykwaardigheid van vroue te bevorder.

- Homofobiese haatspraak: Sedert die tagtigerjare van die vorige eeu is die Christelike etiek in die westerse wêreld toenemend met die saak van homoseksualiteit gekonfronteer (vgl. Keane 1980; Moberley 1983; Douma 1984; Gudorf 2000). Hierdie konfrontasie is deur die opkomende menseregtekultuur meegebring wat gepleit 
het dat die reg van homoseksuele mense erken moet word om self keuses oor die hantering van hulle seksuele oriëntasie te maak. Verder word daar 'n saak voor uitgemaak dat homoseksuele persone dieselfde regte as alle ander mense in die samelewing moet geniet. Hierdie regte sluit in dat hulle in staat behoort te wees om met mense van dieselfde geslag ' $n$ huwelik te kan sluit en kinders aan te neem. Menseregte organisasies en sommige kerke het die tradisionele opvattings oor homoseksualiteit die stryd aangesê en vir die bevryding van persone met 'n homoseksuele oriëntasie gestry (vgl. Johnston 1983:107). Twintig jaar later word die moderne westerse samelewing ten opsigte van hierdie saak nou deur twee uiteenlopende tendense gekenmerk. Die een tendens is dat homoseksuele gedrag as normale gedrag beskou word en dat die huwelik tussen homoseksuele mense gewettig word. Nederland het in die wettiging van die homoseksuele huwelik die voortou geneem en in SuidAfrika is dieselfde pad in 2006 gevolg (SA 2006:2). Die Suid-Afrikaanse regering het sy wet op die oordeel van regslui gegrond, naamlik dat 'n verbod op homoseksuele huwelike die grondwet se grondwaardes van vryheid en gelykheid aantas. Homoseksuele gedrag word in die reg en ook in die menswetenskappe al hoe meer as normale gedrag getipeer. Hierdie tendens het egter ook ' $n$ fel teenreaksie ontketen. Konserwatiewe godsdiensgroepe en inheemse kulture wat die normalisering van homoseksuele gedrag in die westerse lande as immoreel en in stryd met hulle eie lewenswaardes beskou, antwoord daarop met wat beskryf kan word as homofobie. Hierdie term omskryf'n gesindheid van haat en dade van aggressie, wantroue en verontregting teenoor persone met 'n homoseksuele oriëntasie. Soos die normalisering van homoseksuele gedrag toegeneem het, het homofobie en homofobiese haatspraak ook toegeneem. Erkenning van die regte van homoseksuele persone in die algemene regsverkeer en in sosiale strukture moet verwelkom word. Hierdie regte is gegrond in die grondwaardes van menswaardigheid, vryheid en gelykheid wat ook in die Christelike etiek hoog aangeslaan word. Oor die legitimering van burgerlike verbintenisse is daar egter verskille. Op hierdie saak word nie hier ingegaan nie. Homofobiese gedrag en haatspraak moet egter afgewys word, omdat dit soos alle ander haatspraak strydig is met die derde gebod. Hierin het kerke 'n groot taak, omdat homofobiese haatspraak dikwels op godsdienstige gronde geregverdig word.

\section{Gevolgtrekking}

Die naam van God is 'n beskrywing van sy wese. Die wese van God word in die $\mathrm{Ou}$ en die Nuwe Testament uitgelê as God in gemeenskap met mense. Hierdie gemeenskap word as 'n liefdesgemeenskap gekarakteriseer wat deur God self geïnisieer en in stand gehou word. Alle gedrag wat hierdie liefdesgemeenskap aantas, moet afgewys word. Haatspraak is verbale gedrag wat op grond van sosiale verskille mense se menswaardigheid aantas en daardeur ook die liefdesgemeenskap wat in die wese van God opgesluit lê. Alle vorms van haatspraak is dus strydig met die derde gebod. In die Suid-Afrikaanse gemeenskap is haatspraak op godsdienstige gronde en rassistiese, xenofobiese, seksistiese en homofobiese haatspraak prominent. Kerke en Christene behoort veral daarteen te getuig en leiding in die samelewing te neem om dit te bestry.

\section{Erkenning Mededingende belange}

Die outeur verklaar dat hy geen finansiële of persoonlike verbintenis het met enige party wat hom nadelig kon beïnvloed het in die skryf van hierdie artikel nie.

\section{Literatuurverwysings}

Barth, K., 1961, Church dogmatics: The doctrine of reconciliation, Vol. 4, pt. 2, Clark, Edinburgh.

Bestler, L., 2013, Examples of racist speech, viewed 09 May 2013, from http//www. laurabestler.org/examples-of-racist-speech/

Bremner, C., 2010, 'Burka makes women prisoners, says President Sarkozy', Times online 23 June 2009, viewed 09 March 2010 from http//www.Timesonline.co.uk/ tol/news/world/Europe/article6557252.ece

Bright, J., 1963, The kingdom of God, Abingdon, New York.

Brueggemann, W., 2009, An unsettling God: The heart of the Hebrew Bible, Fortress, Minneapolis.

Brunner, E., 1949, The Christian doctrine of God: Dogmatics, Vol. 1, transl. by O. Wyon, Lutterworth, London.

Camp, R.L., 1990, 'Women in the Catholic Church', Catholic Historical Review 76(3), 506-515.

Campbell, D.A., 2003, 'Reconciliation in Paul: The gospel of negation and transcendence in Galatians 3:28', in C.E. Gunton (ed.), The theology of reconciliation, pp. 30-65, in Galatians 3:
Clark, London.

Cullmann, O., 1948, Christus und die Zeit: Die Uhrchristliche Zeit- und Geschicht-Aufassung, Evangelisher Verlag, Zürich.

De Vaux, R., 1988, Ancient Israel: Its life and institutions, transl. by J. McHugh, Darton, Longman \& Todd, London.

Devenish, G.E., 1999, A commentary on the South African Bill of Rights, Butterworths, Durban.

Dille, S.J., 2004, Mixing metaphors: God as mother and father in Deutero-Isaiah, Clark, London.

Douma, J., 1984, Homofilie, Van den Bergh, Kampen.

Douma, J., 1996, The Ten Commandments, P \& R Publishing, Phillipsburgh.

Farrow, D., 2003, 'Ascension and atonement', in C.E. Gunton (ed.), The theology of reconciliation, pp. 67-92, Clark, London.

Finlayson, R.A., 1970, 'The Fatherhood of God', in J.D. Douglas (ed.), The New Bible Dictionary, p. 477, InterVarsity, London.

Gassmann, B., 1968, Ecclesia Reformata: Die Kirche in den Reformierten BekenntnisSchriften, Herder, Freiburg.

Gloer, W.H., 2007, 'Ambassadors of reconciliation: Paul's genius in applying the gospel in a multicultural world: 2 Corinthians 5:14-21', Review and Expositor (3), 589-601.

Goldingay, J., 2006, Old Testament theology, Vol. 2: Israel's faith, InterVarsity, Downers Grove.

Grim, B.J., 2012, 'Rising restrictions on religion', International Journal of Religious Freedom 5(1), 17-33.

Gudorf, C., 2000, 'The Bible and science on homosexuality', in D.L. Balch (ed.), Homosexuality, science and the 'plain sense' of Scripture, pp. 121-141, Eerdmans, Grand Rapids.

Harman, A.M., 1988, 'The interpretation of the third commandment', The Reformed Theological Journal 67(1), 1-7.

Hasel, G., 1991, Old Testament theology: Basic issues in the current debate, Eerdmans, Grand Rapids.

Johnson, D.J., 2005, 'WatuWaAmani (People of Pece): An African theology of liberation and reconciliation from the historic peace churches in Africa', Brethren Life and Thought 52(10), 16-31.

Johnston, M., 1983, Gays under grace: A gay Christian's response to the moral majority, Winston-Derek, Nashville.

Keane, P.S., 1980, Sexual morality: A Catholic perspective, Gill \& Macmillan, Dublin.

Kiska, R. \& Coleman, P., 2012, 'Freedom of speech and "hate speech": Unravelling the jurisprudence of the European Court of Human Rights', International Journal of Religious Freedom 5(1), 129-142.

Küng, H., 1992, The church, Burns \& Oates, Kent.

Moberly, E.R., 1983, Homosexuality: A new Christian ethic, Clarke, Cambridge. 
Moltmann, J., 1993, God in creation, Fortress, Minneapolis.

Packer, J.I., 1988, 'God' in S.B. Ferguson \& J.F. Wright (eds.), New Dictionary of Theology, pp. 274-277, InterVarsity, Downers Grove.

Patterson, S., 2003, 'Between women and men', in C.E. Gunton (ed.), The theology of reconciliation, pp. 125-140, Clark, London.

Reuman, J., 2005, 'Salvation history', in E. Fahlbusch, J.M. Lochman, J. Mbiti, J. Pelikan \& L. Vischer (eds.), The Encyclopaedia of Christianity, vol. 4, pp. 832-836, Brill, Leiden.

Ridderbos, H., 1969, The coming of the kingdom, The Presbyterian and Reformed Publishing Company, Philadelphia.

Ridderbos, H., 1971, Paulus: Ontwerp van zijn theologie, Kok, Kampen.

Routledge, R., 2008, Old Testament theology: A thematic approach, InterVarsity, Nottingham.

Schüssler-Fiorenza, E., 1998, Sharing her word: Feminist biblical interpretation in context, Clark, Edinburgh.

Schutte, G., 1995, What racists believe: Race relations in South Africa and the United States, Sage, London.
Suid-Afrika, 1996, Grondwet van die Republiek van Suid-Afrika, Staatsdrukker, Pretoria. Suid-Afrika, 2006, Civil Unions Act, No 17 of 2006, Government Gazette, Cape Town. Turner, M., 2007, 'Human reconciliation in the New Testament with special reference to Philemon, Colossians and Ephesians', European Journal of Theology 16(1), 37-47.

United Nations, 1995, The United Nations and Human Rights 1945-1995, United Nations, New York.

United Nations, 1996, The United Nations and the Advancement of Women, United Nations, New York.

Vorster, J.M., 2007, Christian attitude in the South African liberal democracy, Potchefstroom Theological Publications, Potchefstroom

Vorster, J.M., 2011, 'Banning the burq'a? An ethical appraisal', Journal of Reformed Theology 5(2011), 63-80.

Vriezen, Th.C., 1966, Hoofdlijnen der theologie van het Oude Testament, Veenman, Wageningen.

Willmer, H., 2007, "Vertical" and "horizontal" in Paul's theology of reconciliation in the letter to the Romans', Transformation 24(374), 151-160. 